\title{
Formation of thrust-block moraines at the margins of dry- based glaciers, south Victoria Land, Antarctica
}

\author{
SEAn J. Fitzsimons \\ Department of Geography, University of Otago, P.O. Box 56, Dunedin, New Zealand
}

\begin{abstract}
Several dry-based alpine glaciers in the Dry Valleys of south Victoria Land, Antarctica, have prominent end moraines. Examination of their morphology, structure and sedimentology shows they consist of blocks of sand, gravel and organic silt within which sedimentary structures unrelated to entrainment and transportation by ice are well preserved. The nature and preservation of sedimentary structures, together with the presence of algae mats in the sediment, suggest formation by proglacial entrainment, transportation and deposition of frozen blocks of lacustrine sediment. Previous explanations of the formation of thrust-block moraines, including those that stress the importance of elevated pore-water pressure and Weertman's icedebris accretion hypothesis, depend on the presence of subglacial meltwater or the $0^{\circ} \mathrm{C}$ isotherm being situated close to the glacier bed. These models appear inappropriate for cold, dry-based glaciers because their basal temperatures are well below freezing point and they rest on deep permafrost. Three alternative models for the formation of thrust-block moraines at the margins of dry-based glaciers are examined in this paper: block entrainment of sediment associated with frozen-bed deformation; entrainment by overriding and accretion of marginal-ice and debris aprons; and transient wetbased conditions associated with glaciers flowing into ice-marginal lakes.
\end{abstract}

\section{INTRODUGTION}

Two main types of glaciotectonic deformation are proglacial deformation at the margin of glaciers and subglacial deformation beneath glaciers (Hart and Boulton, 1991). Proglacial deformation ranges from plastic deformation of unfrozen sediment to brittle deformation of frozen unconsolidated sediment or rock. Ridges resulting from proglacial deformation are known as pseudo-moraines, push moraines, ice-pushed ridges, push ridges and ice-thrust ridges. They are distinguished from other moraines by being structural rather than constructional features (Kupsch, 1962). The name push moraines is used as a general term for ridges resulting from proglacial glaciotectonic deformation (Boulton, 1986). The term thrust-block moraines, used in this paper, denotes ridges that have formed by proglacial thrusting and stacking of blocks of frozen unconsolidated sediment (Klassen, 1971; Evans, 1989a). Although earlier studies of push moraines considered that frozen materials were essential (Hart and Boulton, 1991), most research on proglacial and subglacial glaciotectonics suggests that deformation is more likely to be associated with unfrozen conditions, particularly where elevated pore-water pressure reduces the shear strength of materials (Moran, 1971; van der Wateren, 1975; Moran and others, 1980; Moores, 1990). Hart and Boulton (1991) concluded that although glaciotectonic deformation can act on both frozen and unfrozen materials, the question of how to differentiate these states in ancient sediments requires more detailed research. There is a need to narrow the gap between theories of glaciotectonic deformation and interpretation of the sedimentary and morphological record. There is a particular need to examine sediment deformation and entrainment at the margins of dry-based glaciers, of which there have been few studies of the basal conditions and even fewer of conditions of dry-based ice resting on unconsolidated sediment (Echelmeyer and Wang, 1987).

Glaciers in the Dry Valleys can be divided into those confined to the valley sides and resting on bedrock, and those that reach valley floors and rest on frozen unconsolidated sediment Humphreys and Fitzsimons, in press). Glaciers that reach the valley floor, particularly those with ice-marginal lakes, have distinctive icemarginal sediments and landforms. Previous studies of ice-marginal landforms associated with these glaciers have not examined the internal structure of the moraines, and models of moraine formation emphasise observable contemporary depositional processes (e.g. Selby, 1973; Rains and Shaw, 1981). This study focuses on the structure and composition of ice-marginal landforms and attempts to link the sedimentary products of proglacial deformation with glaciological processes.

The objectives of this study are to (1) determine the morphologies, composition and structure of moraines at the margins of alpine glaciers, (2) evaluate existing models for the formation of the moraines, and (3) develop a generally applicable model for their formation. 


\section{FIELD AREA AND METHODS}

The Dry Valleys are ice-free valleys shaped by glaciers flowing from inland ice to the Ross Sea (Fig. 1). Three types of glacier exist in the valleys: outlet glaciers such as Taylor Glacier that drain the east Antarctic ice sheet; piedmont glaciers that occupy low coastal hills; and small alpine glaciers (Fig. 1). The mean annual temperature at Vanda Station in the Wright Valley is $-19.8^{\circ} \mathrm{C}$ (Schwerdtfeger, 1970). Rainfall is unknown, snowfall is light (approximately $10 \mathrm{~mm}$ w.e. a ${ }^{1}$ : Chinn, 1990) and most of the area experiences a water deficit. The small alpine glaciers have a thermal regime where the whole glacier is below pressure-melting point (Chinn, 1991) and typical basal temperatures range between $-18^{\circ}$ and $-15^{\circ} \mathrm{C}$ (Holdsworth and Bull, 1970; Boulton, 1979). Current understanding of these glaciers suggests all movement occurs by ice deformation concentrated in the lowermost metre, and they are almost incapable of basal erosion (Holdsworth and Bull, 1970; Chinn, 1991). For this study the marginal landforms and sediments of ten alpine glaciers and Wright Lower Glacier were surveyed Fig. 1). Eight of the glaciers do not have prominent end moraines, so the work focused on Suess and Wright Lower Glaciers which have well-developed ice-cored moraines that are easily accessible. Field-work consisted of surveying the ridges, excavating the surface debris mantle of the moraines and recording their structure and sedimentology.

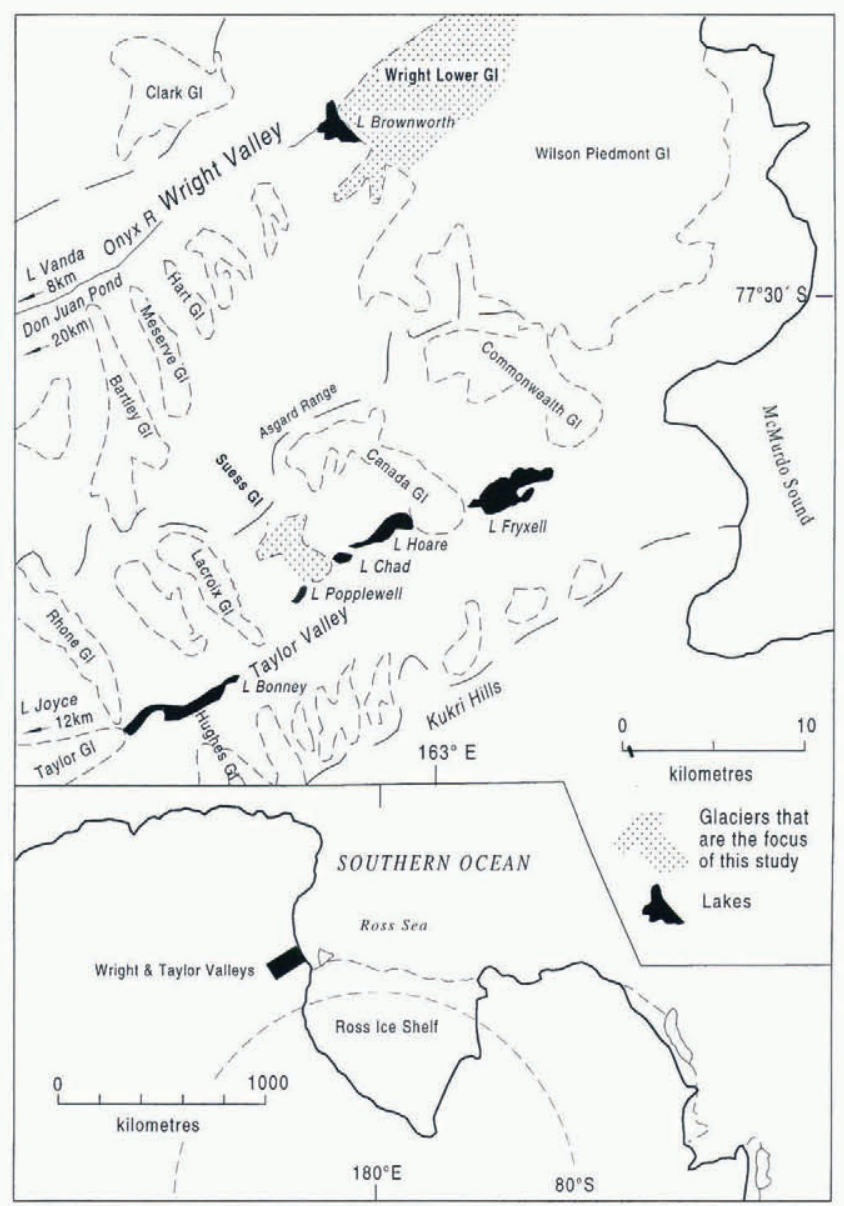

Fig. 1. Location map.

\section{MORPHOLOGY, STRUCTURE AND SEDIMENTOLOGY OF THE MORAINES}

\section{Right margin of Suess Glacier}

Suess Glacier is a small alpine glacier that descends from $1750 \mathrm{~m}$ on the Asgard Range and flows across the floor of the Taylor Valley (Fig. 1). The right terminus of Suess Glacier flows southwest up the Taylor Valley, and the left terminus flows northeast towards the Ross Sea. The right terminus forms an $18 \mathrm{~m}$ cliff adjacent to Lake Popplewell Fig. 2a). A small gravel ridge projects from the ice-anddebris apron below the ice cliff (Fig. 3a). Excavation of the ridge reveals thin, planar beds and rare cross-beds of sands, fine gravels and occasional organic muds (Fig. 2b). The bedding of the sediments dips steeply in an up-glacier direction, and in several locations there is an angular unconformable contact within the sediment (Fig. 2b). The particle-size characteristics of the sediments are similar to adjacent lacustrine environments, particularly the sorting and mean size values (Table 1). Exposures of the upper part of the basal debris zone show blocks of bedded sediment entrained by the glacier (Fig. 2c).

\section{Left margin of Suess Glacier}

The left terminal margin of Suess Glacier has high icecored moraines that lie between the ice cliff and the shore of Lake Chad (Fig. 4). Three distinct ridges can be identified: a low frontal ridge with a sandy debris cover, and two high boulder-covered ridges (Fig. 4b). Differences in the texture of sediments on the two ridges reflect different sediment sources. The fine-grained frontal ridges consist of blocks of well-sorted sand and fine gravel, and the large boulder-covered ridges consist of blocks of moderately well-sorted gravel and sandy gravel (Fig. 4b). The unstable moraine slopes are $\leq 36^{\circ}$ and have a series of small steps representing the outcrop of bands of sediment that have a steep up-glacier dip (Fig. 3b). Excavations in the small, fine-grained moraine on the left of Figure 4 show the sediment layers with planar-bedded, poorly sorted to well-sorted sands, occasional boulders and fine gravels that dip steeply in an up-glacier direction (Fig. 3b; Table 1).

\section{Wright Lower Glacier}

Wright Lower Glacier is a lobe of Wilson Piedmont Glacier that extends into the Wright Valley. At the terminus a series of moraine ridges lies next to and on the frozen surface of Lake Brownworth. The moraines consist of a series of sharp-crested, ice-cored ridges parallel to the ice margin (Fig. 3c) with a debris cover ranging from well-sorted fine gravels to coarse, bouldery gravel. Excavations of the surface of ridges show they consist of layers of gravel, sand and sandy organic mud separated by ice. The ice layers include massive clear ice, bubbly clean ice and ice with organic silt clasts (Fig. 5). Most sediments are moderately well or well sorted (Table 1). Strata in the ridges dip steeply in an up-glacier direction, although some ridges contain complexly deformed ice and debris strata. Deformation structures suggest the ice and debris layers were folded and faulted after entrainment. 

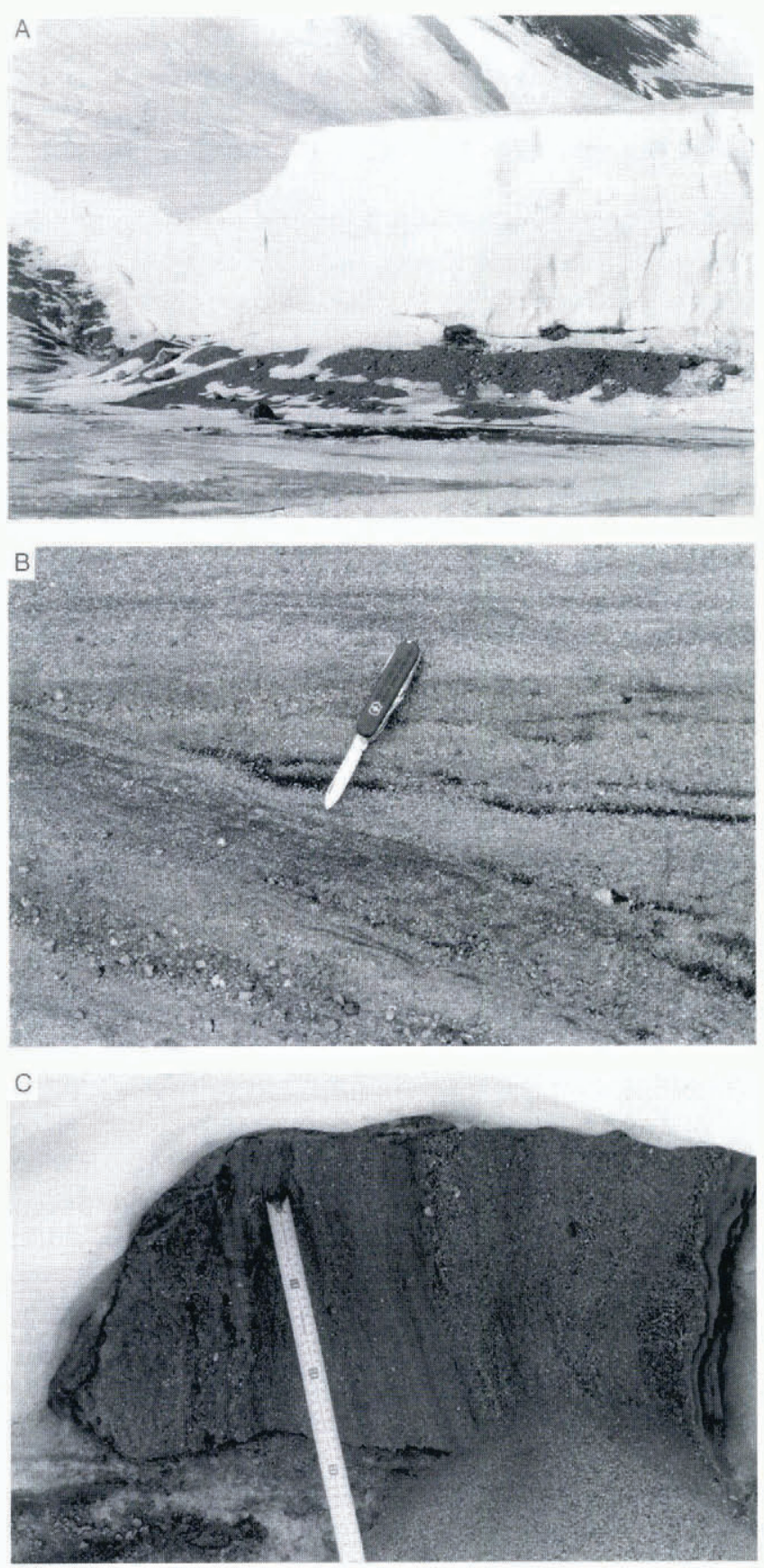

Fig. 2. (a) Right margin of Suess Glacier showing a small marginal-stream channel and delta at Lake Popplewell, and the small moraine ridges at the foot of the $18 \mathrm{~m}$ ice cliff. (b) Angular contact between two thrust blocks. The dark laver, just above the point of the blade, is a layer of algae. (c) Block of planar-bedded sand and gravel in the upper part of the basal debris zone of Suess Glacier.

\section{INTERPRETATION}

The moraines described above are thrust-block moraines formed by entrainment and deformation of proglacial sediments. The well-sorted nature of the sediments in the ridges, together with well-preserved sedimentary structures and beds of algae, suggests that most sediments have accumulated in a shallow lacustrine environment. At Wright Lower Glacier the widespread occurrence of organic mud suggests accumulation in a deeper lake.
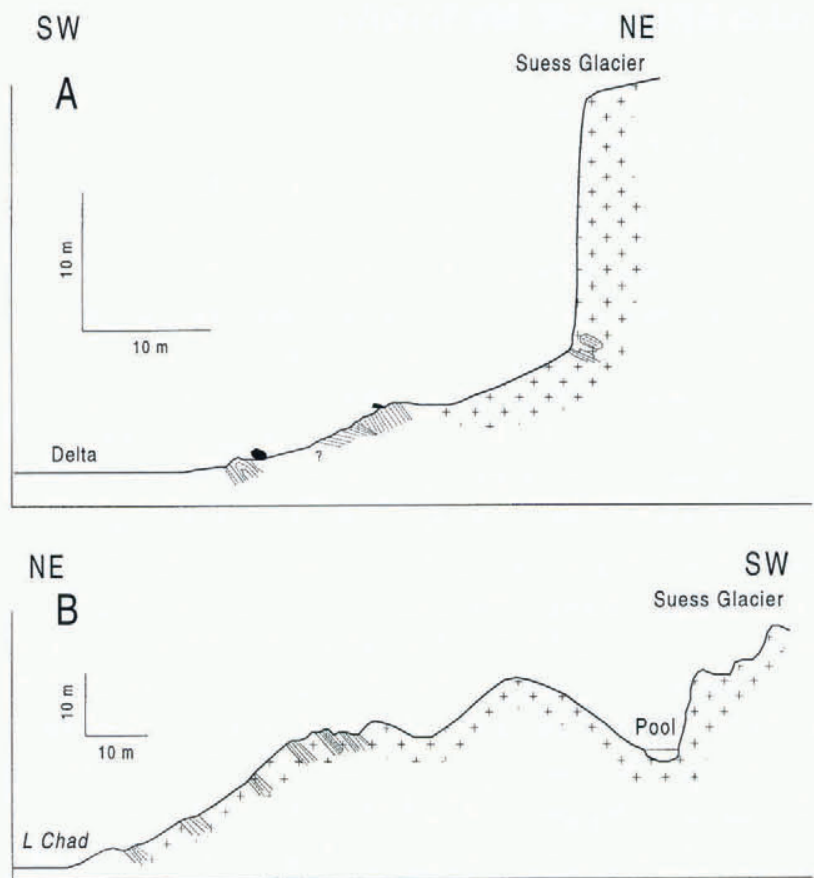

SW

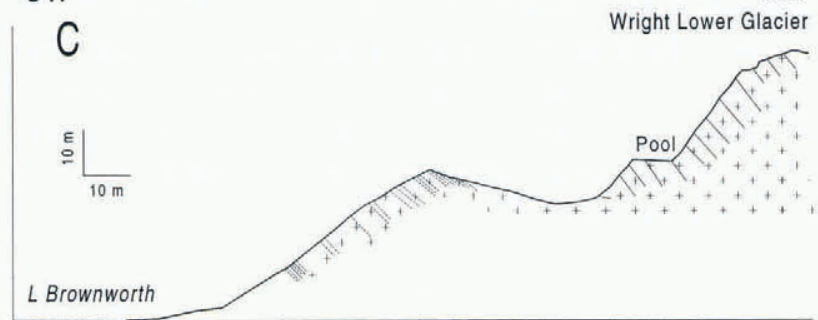

Fig. 3. Cross-sections of thrust-block moraines at the margins of glaciers in the Dry Valleys. The cross-sections are based on surveys and excavations. (a) Right margin of Suess Glacier showing two small, stacked thrust blocks projecting from the ice-debris apron. (b) Left margin of Suess Glacier. Surface sediments on the ridge consist of poorly sorted angular, bouldery sediments. Small steps in the surface of the moraine occur where sediment layers crop out. (c) Wright Lower Glacier. Surface sediments consist of sandy gravel with occasional boulders. Excavations show that the moraine consists of beds of well-sorted sediments separated by layers of ice.

Well-preserved primary sedimentary structures in the moraines and sediment blocks within the glacier suggest the sediments were frozen during entrainment (Fig. 2b). Thus, the most likely scenario is that the moraines are produced by entrainment and deformation of unconsolidated valley-floor sediments.

\section{DISGUSSION}

Proglacial glaciotectonic deformation and the formation of glaciotectonic ridges from proglacial sediment has been widely described (Kupsch, 1962; Moran, 1971; Boulton, 1986; Evans, 1989a). Such deformation has been associated with decreased material shear strength as a consequence of elevated pore-water pressures (Moran and others, 1980; Moores, 1990) and entrainment of substrate 
Table 1. Parlicle-size dala for thrust-block moraine sediment

Sample location

$$
\underset{\text { size }}{\text { Mean particle }} \quad \text { Sorting }{ }^{\dagger}
$$

o)

$\begin{array}{lcl}\text { Moraine, left margin of Suess Glacier } & 1.6 & \text { moderately well sorted }(0.5) \\ \text { Moraine, left margin of Suess Glacier } & -0.5 & \text { moderately sorted }(0.95) \\ \text { Moraine, left margin of Suess Glacier } & 1.56 & \text { well sorted }(0.36) \\ \text { Moraine, right margin of Suess Glacier } & 0.88 & \text { poorly sorted }(1.28) \\ \text { Moraine, right margin of Suess Glacier } & 0.62 & \text { poorly sorted }(1.98) \\ \text { Moraine, Wright Lower Glacier } & -0.24 & \text { moderately sorted }(0.75) \\ \text { Moraine, Wright Lower Glacier } & -0.1 & \text { very well sorted }(0.26) \\ \text { Ice-marginal delta } & 1.06 & \text { moderately well sorted }(0.5) \\ \text { Shallow lacustrine sediment } & 1.8 & \text { moderately well sorted }(0.5) \\ \text { Diamict from Taylor Glacier } & -2.5 & \text { very poorly sorted }(2.1)\end{array}$

* Folk and Ward (1957) phi value.

† Folk and Ward (1957) sorting classification and phi value.

to fluctuation of the position of the $0^{\circ} \mathrm{C}$ isotherm close to the glacier bed. The field evidence and interpretation
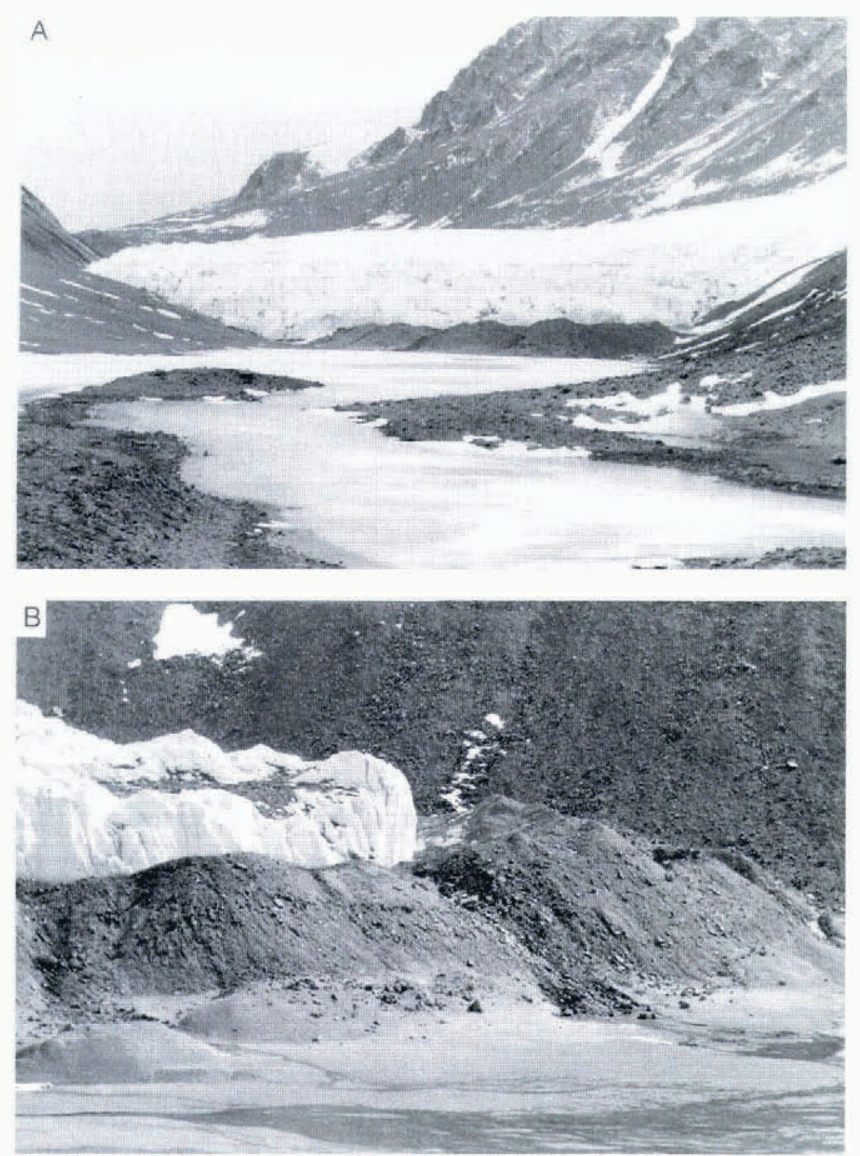

Fig. 4. Left margin of Suess Glacier. (a) High, bouldercovered, ice-cored moraines adjacent to Lake Chad. The moraine ridge forms an extension of the lateral moraine on the right. (b) In front of the larger moraine, low sandy ridges consist of blocks of planar-bedded sand that are thrust blocks of fine-grained deltaic sediment. The main ridge is about $20 \mathrm{~m}$ high. presented above appears inconsistent with existing models of proglacial glaciotectonic deformation and with opinion that dry-based glaciers are only capable of limited erosion (Boulton, 1979).

Three alternative models for the formation of thrustblock moraines at the margins are examined below: block entrainment of frozen sediment associated with frozen-

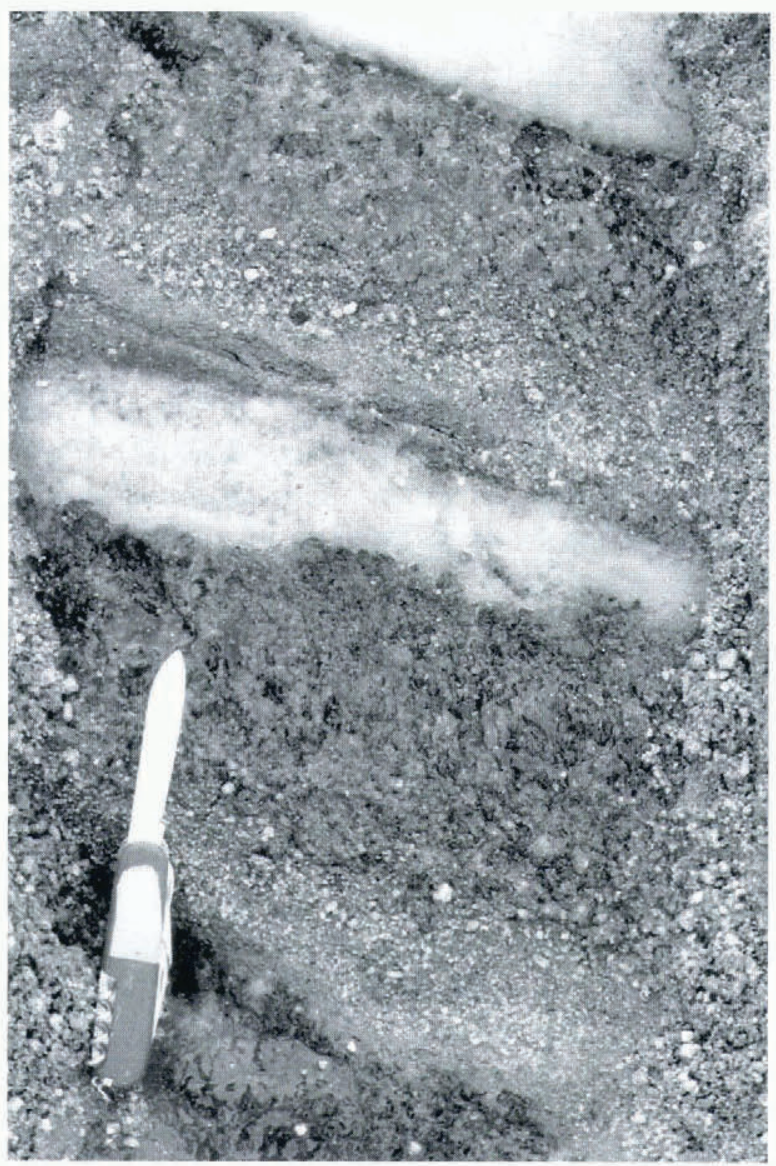

Fig. 5. Bedded fine gravel, coarse sand and ice in thrustblock moraines at the margin of Wright Lower Glacier. 
bed deformation; the apron-entrainment model for polar glaciers; and transient wet-based conditions associated with glaciers flowing into ice-marginal lakes.

Theoretical and laboratory studies of the rheological behaviour of frozen debris suggest that the viscosity of frozen debris is orders of magnitude greater than that of clean ice (Hooke and others, 1972; Nickling and Bennett, 1984). If this is the case, a frozen, unconsolidated substrate would be unimportant in the flow of polar ice masses (Echelmeyer and Wang, 1987). However, observations made in a tunnel at the base of sub-polar Ürümqi No. 1 Glacier in China have demonstrated three mechanisms of flow at sub-freezing temperatures in the lowermost $1-2 \%$ of the glacier: enhanced deformation of frozen debris; motion across discrete shear planes within and at the surface of frozen drift; and basal sliding at an ice/rock interface (Echelmeyer and Wang, 1987). Echelmeyer and Wang concluded that $60 \%$ of the overall ice-surface motion occurs by deformation of a layer of basal drift $35 \mathrm{~cm}$ thick. In contrast to laboratory studies, they found that the viscosity of the debris was more than two orders of magnitude less than the viscosity of the overlying ice. The implications of these observations are that deformation of frozen substrate could play an important role in the dynamics of polar ice masses and provide a means of entraining blocks of sediment beneath dry-based ice. While this mechanism provides a potential explanation for the formation of some thrust-block moraines in the Dry Valleys, it does not explain the ice resting between the layers of sediment in the moraines (Fig. $3 \mathrm{~b}$ and c).

Shaw (1977) developed a model of debris entrainment for a cold-based glacier based on the morphology of glacier margins and flow patterns in ice fronts (Holdsworth and Bull, 1970). The model is based on overriding and entrainment of the ice and debris aprons that are characteristic of dry-based glaciers (Evans, 1989b). The aprons consist of fallen ice blocks, refrozen meltwater, supraglacial debris from the glacier surface, englacial debris and wind-blown sediment. Reworking of accumulated sediment on the apron by mass flow and running water, together with intermittent block falls, gives rise to crude stratification of the debris and alternation of high and low debris concentrations. The apron-incorporation model does not explain the formation of thrust-block moraines, since the sediments contain primary sedimentary structures indicative of fluvial and lacustrine deposition that does not occur on aprons. The presence of algae beds in the moraines is also inconsistent with apron entrainment because conditions conducive to the growth and accumulation of algae are not maintained on aprons. In addition, the apron-entrainment model does not fully explain the debris bands that lie above and are separated from the basal debris zone by clean ice (Fig. 2b). Shaw suggested that this apparent anomaly may be explained by the basal freezing mechanism proposed by Weertman (1961), a sustained period of wind-drift snow accumulation followed by entrainment, thereby forming a wedge of clean ice, or basal freezing as the glacier crossed a lake.

The thrust-block moraines described in this study form adjacent to ice-marginal lakes. Lakes in the Dry Valleys can be divided into three thermal types Chinn,
1993): wet-based lakes that have a permanent ice cover over water that does not freeze to the ground; dry-based lakes which freeze completely; and lakes that have very high salinity and do not freeze. In wet-based lakes heat is conducted downward through the permanent surface ice to the water below (Wilson and others, 1974). Strong density stratification means the lakes become heat sinks, and bottom water temperatures range from $26^{\circ} \mathrm{C}$ (Lake Vanda) to $2.3^{\circ} \mathrm{C}$ (Lake Fryxell; Chinn, 1993). Heat conducted downward through the bottom of lakes results in unfrozen sediment. For example, Don Juan Pond in the Wright Valley has a bed of $12.6 \mathrm{~m}$ of unfrozen sediment (Cartwright and Harris, 1978).

When a glacier flows into a lake, two possible regimes that can develop are melting or freezing. The melt or refreezing rate $(M)$ has been calculated by Doake (1976) from:

$$
M=\frac{\left(Q_{\mathrm{s}}-Q_{\mathrm{i}}\right)}{\rho_{\mathrm{i}} L}
$$

where $Q_{\mathrm{s}}$ is the is the upward heat flux through the water, $Q_{\mathrm{i}}$ is the heat flux through the ice, $\rho_{\mathrm{i}}$ is the density of ice, and $L$ is the latent heat of fusion. $Q_{\mathrm{s}}$ is a function of temperature above freezing, flow characteristics and convection. $Q_{\mathrm{i}}$ is the product of temperature gradient in the ice and thermal conductivity. In the case of a cold glacier flowing into a lake, heat flow from the relatively warm water to the ice causes melting. However, where circulation is weaker, for example beneath the glacier, the heat flow from water to ice will continue until the water and ice equilibrate. In the case of water at around $5^{\circ} \mathrm{C}$ and ice at $-15^{\circ} \mathrm{C}$ it is likely that ice and water-saturated debris will freeze to the glacier ice. Thus, as ice flows into a lake there are transient conditions that facilitate the accretion of ice and water-saturated debris to the glacier. This mechanism provides a potential explanation for the structure and composition of the thrust-block moraines.

Several lakes in the Dry Valleys area have very high salinity (Torii and others, 1981). The freezing point of saline water can be calculated using an equation from Doronin and Kheisin (1977):

$$
\mathrm{Fp}=-\left(3+52.7(\mathrm{sal})+0.04\left(\mathrm{sal}^{2}\right)+0.0004\left(\mathrm{sal}^{3}\right)\right) 10^{-3}
$$

where $\mathrm{Fp}$ is the freezing point and sal is salinity. This polynomial can be verified for hypersaline waters using an experimentally derived freezing point for water from Deep Lake in the Vestfold Hills. Deep Lake has an average salinity of $280 \mathrm{~g} \mathrm{l}^{-1}$, and begins to freeze at $-28^{\circ} \mathrm{C}$ (Kerry and others, 1977). Equation (2) gives a freezing point of $-26.7^{\circ} \mathrm{C}$ for this salinity, and can be regarded as reasonably accurate for indication of freezing-point temperature. Table 2 shows the salinity and freezingpoint temperatures calculated using Equation (2) for several lakes in the Dry Valleys. These data show that some lakes will not freeze if a glacier at $-20^{\circ} \mathrm{C}$ overrides them. Perhaps more importantly, Torii and others (1981) have suggested that the ground-water around saline lakes has essentially the same chemical composition as the lake water. Consequently, it is possible that dry-based alpine glaciers descending from valley sides could become "wet- 
Table 2. Salinity and freezing-point temperatures for saline lakes in the Dry Valleys

\begin{tabular}{lccc}
\hline Lake & Salinity & Depth & $\begin{array}{c}\text { Freezing } \\
\text { point }\end{array}$ \\
& $\mathrm{g} \mathrm{kg}{ }^{1}$ & $\mathrm{~m}$ & $\mathrm{C}^{\dagger}$ \\
\hline Joyce & 4.1 & 30 & -0.22 \\
Fryxell & 7.5 & 16 & -0.42 \\
Pond at Labybrinth & 16.4 & 0 & -0.9 \\
Seawater & 35 & 0 & -1.9 \\
Vanda & 113.3 & 64.4 & -7.1 \\
Bonney (W lobe) & 126.4 & 29.5 & -8.1 \\
Bonney (E lobe) & 247.9 & 32.5 & -21.6 \\
Don Juan & 392.4 & 0 & -51.0 \\
& & &
\end{tabular}

\footnotetext{
* From Torii and others (1981).

$\dagger$ Calculated using Equation (2).
}

based" when they reach unconsolidated sediment on the valley floor. However, this mechanism is not appropriate for the explanation of the Wright Lower Glacier thrustblock moraines because Lake Brownworth is a fresh-water lake.

Figure 6 presents a depositional model for the formation of thrust-block moraines at the margins of dry-based glaciers that flow into lakes. The model is based on inferences from the morphology, sedimentology
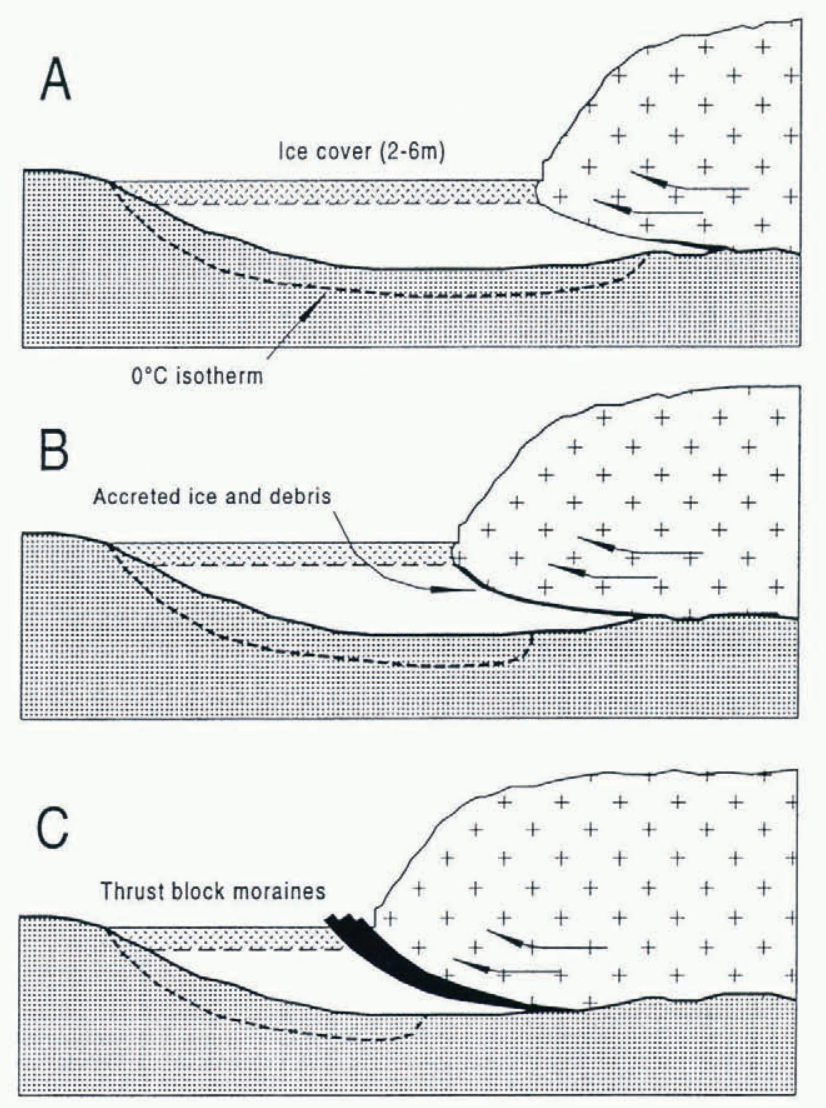

Fig. 6. Depositional model for the formation of thrustblock moraines at the margins of dry-based glaciers that flow into lakes. See lext for explanation. and structure of the moraines and radio-echo sounding of Lake Brownworth (Chinn and Maze, 1983). However, it is speculative because the processes occurring at the glacier/lake interface have not been directly observed.

Warm lakes in the Dry Valleys maintain unfrozen beds and are likely to have a strong influence on the geometry of ice margins because heat flow from the relatively warm water results in enhanced subaqueous ablation (Fig. 6a). Near the glacier sole where the circulation is weak, conditions of basal freezing can result in ice accretion. In addition, transient wet-based conditions occur as ice flows onto unfrozen sediment of the lake bottom, creating conditions conducive to the entrainment of blocks of sediment (Fig. 6b). Rising flow vectors at the ice terminus Chinn, 1991) result in the upward movement of the accreted ice and debris. Icecored ridges form when debris contained within the accreted ice ablates. Debris continues to accumulate on the surface of the moraines until the debris thickness reaches the thickness of the active layer of the permafrost. After this point the ridges stabilise, because the underlying ice can only be lost by sublimation through the debris cover or by erosion of the debris cover. Thus, the ridges may appear to "float" on the frozen surface of the ice-marginal lake, as occurs at the margin of Lower Wright Glacier (Fig. 6c). For a floating ice margin, conditions are more conducive to ice accretion. Sediment accretion will occur only if the ice grounds or the freezing front reaches the lake bed.

\section{CONCLUSIONS}

Three main conclusions concerning the geomorphology of dry-based glacier margins emerge from this study. First, ridges at the margins of several dry-based glaciers consist of blocks of lacustrine and fluvial sediments that are in some cases interbedded with ice. The sediment blocks and ice appear to have formed by accretion of proglacial sediment and lake water. Secondly, the apron-entrainment model for the operation of dry-based glaciers does not fully explain the entrainment of blocks of valley-floor sediments and the formation of thrust-block moraines. The model requires revision and elaboration. Thirdly, although models of glaciotectonic deformation based on elevated pore-water pressure and Weertman's ice-debris accretion model appear incompatible with the thrustblock moraines, conditions associated with glaciers flowing into ice-marginal lakes may provide a special case of transient conditions of basal freezing consistent with the model.

Several aspects of this study require further investigation. Three of the most important are the significance of proglacial processes in the formation of the basal zone of dry-based glaciers; if deformation of frozen unconsolidated sediments at the bed of dry-based glaciers is common, as suggested by Echelmeyer and Wang (1987), field criteria can be used to recognise such deformation; and whether the composition of accreted ice can be distinguished from lake water and pure glacier ice, as implied in the depositional model outlined above. 


\section{ACKNOWLEDGEMENTS}

The author would like to thank the University of Otago Research Committee for financial support; the Ross Dependency Research Committee for scientific approval; the New Zealand Antarctic Programme and the U.S. Navy for logistical support; T. Chinn for discussions about the ice margins; K. Humphreys and M. Vandergoes for assistance in the field; and W. Mooney for drawing the diagrams.

\section{REFERENCES}

Boulton, G.S. 1979. Processes of erosion on different substrata. J. Glaciol., 23 89), 15-38.

Boulton, G. S. 1986. Push moraines and glacier-contact fans in marine and terrestrial environments. Sedimentology, 33 (5), 677-698.

Cartwright, K. and H.J.H. Harris. 1978. Origin of water in lakes and ponds in the Dry Valley region, Antarctica. [Abstract.] Dry Valley Drilling Project Bull. 8, 8.

Chinn, T.J. H. 1990. The Dry Valleys. In Hatherton, T., ed. Antartica: the Ross Sea region. Wellington, New Zealand, DSIR Publishing, 137153. DSIR Information Series 165. .

Chinn, T.J. 1991. Polar glacier margin and debris features. Mem. Soc. Geol. Ital., 46, 25-44.

Chinn, T.J. H. 1993. Physical hydrology of the Dry Valley lakes. Antarct. Res. Ser., 59, 1-51.

Chinn, T.J.H. and I. Maze. 1983. Hydrology and glaciology, Dry Valleys, Antartica: annual report for 1980-81. Christchurch, Ministry of Works and Development. (Report WS 1188. .

Doake, C. S. M. 1976. Thermodynamics of the interaction between ice shelves and the sea. Polar Rec., 18 112), 37-41.

Doronin, Yu. P. and D. Ye. Kheisin. 1977. Sea ice. New Delhi, Amerind Publishing Co.

Echelmeyer, K. and Wang Zhongxiang. 1987. Direct observation of basal sliding and deformation of basal drift at sub-freezing temperatures. J. Glaciol., 33 113), 83-98.

Evans, D. J. A. 1989a. Apron entrainment of the margins of sub-polar glaciers, north-west Ellesmere Island, Canadian High Aretic. $f$ Glaciol., 35 121), 317-324.

Evans, D.J.A. 1989b. The nature of glacitectonic structures and sediments at sub-polar glacier margins, northwest Ellesmere Island, Canada. Geogr. Ann., 71A (3-4), 113-123.

Folk, R. L. and W. C. Ward. 1957. Brazos River bar: a study of the significance of grain size parameters. J. Sedimentary Petrology, 27, 326.

Hart, J. K. and G. S. Boulton. 1991. The interpretation of glaciotectonic and glaciodepositional processes within the glacial environment. Quat. Sci. Rev., 10 4), 335-350.

Holdsworth, G, and C. Bull. 1970. The flow law of cold ice; investigations on Meserve Glacier, Antarctica. International Association of Scientific Hydrology Publication 86 (Symposium at Hanover 1968 - Antarctic Glaciological Exploration (ISAGE)), 204-216.

Hooke, R. LeB., B. B. Dahlin and M. T. Kauper. 1972. Creep of ice containing dispersed fine sand. J. Glaciol., 11 (63), 327-336.

Humphreys, K.H. and S.J. Fitzsimons. In press. Landform and sediment associations of dry-based glaciers in arid polar environments. Z. Geomorphol.

Kerry, K. R., D. R. Grace, R. Williams and H. R. Burton. 1977. Studies on some saline lakes of the Vestfold Hills, Antarctica. In Llano, G. A., ed. Adaptations within Antarctic ecosystems. Houston, TX, Gulf Publishing Co., 839-858.

Klassen, R. A. 1982. Glaciotectonic thrust plates, Bylot Island, District of Franklin. Geol. Surv. Can. Pap. 82 1A, 369-373.

Kupsch, W. O. 1962. Ice thrust ridges in western Canada. J. Geol., 70 (5), 582-594.

Mooers, H.D. 1990. Ice-marginal thrusting of drift and bedrock: thermal regime, subglacial aquifers, and glacial surges. Can. J. Earth Sci., 27 (6), 849-862.

Moran, S. R. 1971. Glaciotectonic structures in drift. In Goldthwait, R.P., ed. Till: a symposium. Columbus, $\mathrm{OH}$, Ohio State University Press, 127-148.

Moran, S. R., L. Clayton, R. LeB. Hooke, M. M. Fenton and L. D. Andriashek. 1980. Glacier-bed landforms of the prairie region of North America. F. Glaciol., 25 (93), 457-476.

Nickling, W. G. and L. Bennett. 1984. The shear strength characteristics of frozen coarse granular debris. 7. Glaciol., 30 (106), $348-357$.

Rains, R. B. and J. Shaw. 1981. Some mechanisms of controlled moraine development, Antarctica. J. Glaciol., 27 (95), 113-128.

Schwerdtfeger, W. 1970. The climate of the Antarctic. In Orvig, S., ed. Climates of the polar regions. New York, Elsevier, 253 335. (World Survey of Climatology 14.

Selby, M. J. 1973. The termini and moraines of glaciers in the McMurdo Dry Valleys, Antarctica. In Stokes, E., ed. Proceedings of the Seventh. Neu Zealand Geography Conference, August 1972, Hamilton. Christchurch, New Zealand Geographical Society, 247257.

Shaw, J. 1977. Till body morphology and structure related to glacier flow. Boreas, 6 2, $189-201$.

Torii, T., S. Murata and N. Yamagata. 1981. Geochemistry of the Dry Valley lakes. 7. R. Soc. N.Z., 1 (4), 387-399.

Wateren, F. M. van der. 1975. A model of glacial tectonics applied to the ice pushed ridges in the central Netherlands. Bull. Geol Soc. Den., 34. $55-74$.

Weertman, J. 1961. Mechanism for the formation of inner moraines found near the edge of cold ice caps and ice sheets. J. Glaciol., 3 (30), 965-978.

Wilson, A. T., R. Holdsworth and C. H. Hendy. 1974. Lake Vanda: source of heating. Antarct. J. U.S., 9 4), 137-138. 